\title{
Comparison of Organizational Climate in the Regional Unit of the National Institute of Public Health Before and After Reorganization
}

\author{
Gašper Jordan \\ Researcher \\ gasper.jordan77@gmail.com \\ Gozdana Miglič \\ University of Maribor, Faculty of Organizational Sciences; Kranj, Slovenia \\ gozdana.miglic@fov.uni-mb.si \\ Miha Marič \\ University of Maribor, Faculty of Organizational Sciences; Kranj, Slovenia \\ miha.maric@fov.uni-mb.si
}

\section{ABSTRACT}

Organizations have been focused on organizational climate (OC) as one of the influencing factors, which has an impact on organizational outcomes, attaining organizational goals and employee satisfaction. Our research focuses on the regional unit of the National Institute of Public Health in Slovenia and the comparison of the OC before (2013) and after reorganization (2015). We used a modified SiOK (Slovenian Organizational climate) questionnaire to shed light on employees' perception of OC. OC and reorganization are closely connected on account of the relationship between management and employees; if OC is positive, we can expect less complicated process of reorganization as it can be if it is negative. The research revealed misfired attempt of OC improvement in all dimensions, though we expected ameliorated results in the three worst assessed OC dimensions before reorganization. Further, in the paper several recommendations are suggested to managers facing reorganization.

Keywords: organizational climate, reorganization, public sector, human resource management

JEL: 015

Jordan, G., Miglič, G., \& Marič, M. (2016). Comparison of Organizational Climate

Reorganization. International Public Administration Review, 14(4), 71-96. 


\section{Introduction}

Changes in business world on account of economic, political and cultural modifications often make it difficult for organizations to adapt to new circumstances (Soriano, 2012). Nowadays, significance of employees is the core and the driving force of any organization (Bakir Arabacı, 2010; Jordan, 2014). Organization is a live, social and dynamic system with a group of people inside with different mental, economic, social and cultural backgrounds who use interaction to work together. In order to achieve common goals they have to embody each member of the organization (Alipour, 2011). Organizational climate $(\mathrm{OC})$ is one of the crucial elements affiliated with the organization (Isaksen \& Laver, 1999) and closely linked to all other processes and actors in the organization.

$\mathrm{OC}$ is affected by many factors inside organization and has an effect on organizational and psychological process (Samad, 2010). Any new activity or development has an effect, which is reflected in all other areas of the organization with a strong impact on employees. It is very important for the employees to feel loyal to the organization and to identify with its objectives. Leaders must strive to maximize employees' motivation, because by that they will be more receptive to the introduction of innovations, additional work and the quality of the work. Managers often find it wise to take measurements of OC as one of crucial steps in organizational analysis (Thumin \& Thumin, 2011).

Reorganization is a widespread notion. It is the process of organizing something again in dissimilar practice. Organization refers to the new company, while the reorganization relates to an already existing business. The creation of the enterprise is determined by basic organization, but if it subsequently reveals the need for the change of basic organization; the change is called reorganization (Bergant, 1996).

The object of research in this paper was the comparison of OC in the regional unit of the National Institute of Public Health before and after reorganization. The institute as part of the Slovenian public sector was established in 1990s, and it has been growing since then (Boštjančič, 2010). Reorganization included change of headquarters, because the institute merged with another one. That brought different top management and many administrative alternations (name of the institute, new working forms, new information system etc.). In 2008, a new salary system was set by law, which brought decrease in payment for all employees in public sector (Drašler \& Boštjančič, 2015). It has been found that the OC before reorganization was at an average level, but there were two dimensions of the $\mathrm{OC}$ at a rather low level. The best-rated dimensions before reorganization were dimensions Attitudes towards quality and Innovation and initiative, and the worst assessed were Remuneration and Career development. 


\subsection{Organizational climate $(O C)$}

Nowadays, the commonest management issue faced by organizations is search for creative flexible work environment that promotes job satisfaction and innovation (Permarupan, Saufi, Kasim, \& Balakrishnan, 2013). Although there are numerous studies in the field of OC a general definition is still indefinable (Eustace \& Martins, 2014) and it is a researcher's perspective which orientates the definition of the concept (Heyart, 2011). OC is employees' perception of policies, practices and procedures (Schulte, Ostroff, \& Kinicki, 2006; Ancarani, Di Mauro, \& Giammanco, 2009; Imran, Saeed, Anis-Ul-Haq, \& Fatima, 2010; Kallestad, 2010; Benzer et al., 2011; Schneider, Ehrhart, \& Macey, 2012; Barbera \& Schneider, 2014) and the behaviours they notice by getting rewarded, supported and expected (Schneider, Salvaggio, \& Subirats, 2002; Zohar \& Luria, 2005; Barbera \& Schneider, 2014).

OC captures employees' perception of the work practices that affect their daily interactions, which is a potential advantage for organization (Cafferkey \& Dundon, 2015). OC is creation and influence of social context in organization (Açıkgöz \& Günsel, 2011). OC is defined as a psychological and aggregate construct, a system that defines the current characteristics of the organization; it is expressed through the perception of employees how their work environment impacts their own psychological well-being and functioning; it contains soft dimensions of personality of the business system and individuals (Glisson et al., 2012).

The $\mathrm{OC}$ is an important and widely explored psychological construct that refers to the perceptions, feelings, experiences and attitudes developed by people with regard to their working environment: it is a collective perception of the organization, norms and values that manifests itself through sociopsychological dynamics characterizing the group and it has positive or negative influence on individual's behaviour (Ancarani et al., 2009; Castro \& Martins, 2010; D'Alleo \& Santangelo, 2011).

$\mathrm{OC}$ is an important organizational concept. It should be studied scientifically and carefully, looking for crucial elements, which influence it due to impact on organization's effectiveness and defining organizational goals (Organ, Podsakoff \& Mackenzie, 2006). OC is a cognitive interpretation of an organizational situation on the individual level (Çekmecelioğlu \& Günsel, 2013). $\mathrm{OC}$ is defined as member's perception of the characteristics that define and differentiate it (Saungweme \& Gwandure 2011; Villamizar Reyes \& Castañeda Zapata, 2014). They are comparatively durable and are inclined to influence the employees' behaviour (Liou \& Cheng 2010). It is a cluster of elements in organization which is perceived by the employees directly or indirectly and it is presumed as a major factor in influencing employees' behaviour; it has different forces from individual's perspective that characterize each organizational work unit at the same time (James et al., 2008; McMurray, Pirola-Merlo, Sarros, \& Islam, 2010; Alipour, 2011). OC is what employees 
of the organization experience and reflects their values and organizational culture (Sokol, Gozdek, Figurska, \& Blaskova, 2015).

Exploring the $\mathrm{OC}$ is one of the basic approaches to the understanding of the working environment in companies and organizations (Ehrhart \& Kuenzi, 2015). Without knowing the level of your organization's climate, you cannot be a successful manager and you cannot be one of the best in your business. Positive $\mathrm{OC}$ is consequence of good working relationships between management and employees (Pyman, Holland, Teicher, \& Cooper, 2010). The fundamental elements that affect the complete system of OC within the organization are human interaction, satisfaction, loyalty, being at work, cooperation, solidarity, public awareness and autonomy (Mihalič, 2007). OC refers to the shape of the existing conditions and the nature of organizational life that is perceived by employees (Taştan \& Güçel, 2014) and indicates the way things are done in a specific work environment (Villamizar Reyes \& Castañeda Zapata, 2014).

$\mathrm{OC}$ is a multidimensional feature or an organization, ensuing from synergic amalgamation of several vague assets, related to human, relational and structural dimensions of the organization (Carlucci \& Schiuma, 2012, 2014). The working environment that improves the knowledge, skills, abilities and motivation of employees, has a large impact on the performance of the organization (Seghieri, Rojas, \& Nuti, 2014). Each member is a significant part in creating appropriate OC, which fits in organization's strategy and helps to develop human capital for a better social system (Hashim, Ishak, \& Hilmi, 2015).

\subsection{OC's outcomes}

OC has a significant impact on employees' performance and personal wellbeing so it can be used as predictor of employees' motivation enhancement (James et al., 2008; Rusu \& Avasilcai, 2014). Positive OC has strong influence on employees' sense of belonging; they adopt the characteristics of it on individual level, which reflects in variety of employee behavioural outcomes (Taştana \& Güçel, 2014). OC is regarded as important in motivating employees; motivated employees will be more productive, having greater passion for business and better relationship with customers (Permarupan et al., 2013). When employees identify encouraging OC, they show positive behaviours and identification and when they identify uncomfortable working conditions, they incline to commit counterproductive behaviour (Taştan \& Güçel, 2014). OC has a strong influence on employees' behaviour at work and plays a crucial role in any organizational process improvement required by big organizational changes (Carlucci \& Schiuma, 2012, 2014).

Characteristic of negative OC are strict checking of completed work tasks, lack of trust and punishment for insignificant errors (Torka, Schyns, \& Looise, 2010). OC reflects the core of organization; it has been described in words 
as open or closed, positive or negative, personal or impersonal, formal or informal. It can attract individuals without any big effort if it is positive (Mohammadi \& Youzbashi, 2012). OC measures individual's perceptions or feeling about organization (Meyer \& Allen, 1993; Vanaki \& Vagharseyyedin, 2009). OC cannot be changed quickly, because it is a lengthy process (Ceyda \& Sevinc, 2012).

\subsection{SiOK (Slovenian OC)}

At the beginning of 2001, at the initiative of some prominent Slovenian companies, a group of consulting firms under the auspices of the Slovenian Chamber of Commerce prepared a project of research and monitoring $\mathrm{OC}$ in Slovenian organizations named SiOK (Slovenian OC). Now the project is carried out under the auspices of consulting firms rather than in conjunction with the Chamber of Commerce. The guiding idea of the project is a comparative exploration of the $\mathrm{OC}$ and employee satisfaction in order to increase awareness about the importance of climate and learning about appropriate methods for its development. The basic principles of measuring OC are comparable, periodical and quantitative results. The project is in line with the needs of member organizations on the one hand and with the standards of the profession, on the other hand.

In the last three years more than 100 of the most prominent Slovenian organizations and some organizations from abroad participated in the project. Specifically, the project came to life in Croatia, where it has been constantly carried out since 2003 under the name HrOK. A large number of assignments, BA and MA theses were written about this project (Вiro Рraxis, 2013). According to Draškovič \& Erjavšek (2009), the advantages brought by the measurement of OC are better involvement of employees, increased operating efficiency, improved communication among employees, proactive management and the ability to compare with other organizations.

Since 2003 , the research of OC and job satisfaction has always used the same questionnaire. It is possible to compare the average OC in Slovenian companies. Ten years of SiOK practice is empirically proven to be a worthwhile story and should be further developed and used in enterprises. This is mainly reflected in the data of the participating organizations, the number of investigations undertaken and the number of employees involved. At the same time, the participants clearly expressed their desire for the project to develop and live on (OCR Svetovanje in raziskave, 2013). An organization, which chooses to measure the OC, must be prepared for positive or negative results (Draškovič \& Erjavšek, 2009). 


\section{Research Methodology}

\subsection{Research Setting and Sample}

OC plays an important role in every organization. It has a big influence on employees' behaviour and their work performance. Due to that, managers should be checking $\mathrm{OC}$ regularly in order to constantly have motivated and satisfied employees who are the heart of organization. In line with the literature review, the following research question is proposed:

$R Q$ : Has OC in the regional unit of the National Institute of Public Health been improved after reorganization?

To get the answers to the research question, empirical research using the survey instrument was undertaken. A modified SiOK questionnaire was used to estimate $\mathrm{OC}$ in the regional unit of the National Institute of Public Health. The questionnaire comprised 60 statements, 5 statements for each of 12 dimensions, using four-point Likert-type scale (ranging from 1 = 'I strongly disagree', 2 = 'disagree', 3 = 'agree' to 4 = 'I strongly agree'), asking employees to rate their perception about OC. The same questionnaire was used in 2013 and 2015. Respondents were all employees of the Institute. The questionnaire had not been tested, as it had been used for more than 10 years in Slovenia.

The research was founded on two surveys. The first survey was conducted in 2013 before reorganization. The second survey was done in 2015, just after reorganization was fully completed. The advantage of this research is the time period, which enables insight in OC just before and after the process of the reorganization was completed. The questionnaire was distributed to employees via e-mail, using electronic form (https://www.1 ka.si) which was accessible only by a specific password to ensure complete anonymity. A total of 40 out of 63 employees from the regional unit of the National Institute of Public Health returned properly completed questionnaire in 2013, and 41 out of 63 in 2015. The response rate was 63.5\% in 2013 and 65.1\% in 2015.

The collected data was analysed using IBM's Statistical Package for Social Science (SPSS) version 23. Firstly, descriptive statistics were used to calculate means and standard deviations. Secondly, a paired-sampled t-test was carried out to determine if there were statistically significant differences between OC in the regional unit of the National Institute of Public Health before (2013) and after reorganization (2015).

\subsection{Analysis and Results}

The sixty statements were used to measure $\mathrm{OC}$ in regional unit of the National Institute of Public Health before (2013) and after reorganization (2015). The interpretation of t-test results was done at $5 \%$ level of significance (statements with significant difference are marked with *). Results in tables below demonstrate that general level of $\mathrm{OC}$ is not good. High standard deviations show differences among respondents. The t-test results 
Comparison of Organizational Climate in the Regional Unit of the National Institute of Public Health Before and After Reorganization

in Table 1 show that there is significant difference in setting clear goals for standard and quality, dropping from 2.88 in 2013 to 2.20 in 2015.

Table 1. OC dimension Attitude to quality in the regional unit of the National Institute of Public Health before (2013) and after (2015) reorganization

\begin{tabular}{|l|c|c|c|c|c|c|}
\hline \multirow{2}{*}{ 1. ATTITUDE TO QUALITY } & \multicolumn{2}{|c|}{$\begin{array}{c}\text { Before } \\
\text { reorganization }\end{array}$} & \multicolumn{2}{c|}{$\begin{array}{c}\text { After } \\
\text { reorganization }\end{array}$} & \multirow{2}{*}{ T-test } & \multirow{2}{*}{$\begin{array}{c}\text { Sig. } \\
\text { (2-tailed) }\end{array}$} \\
\cline { 2 - 6 } & Mean & SD & Mean & SD & & \\
\cline { 1 - 6 } $\begin{array}{l}\text { As employees, we feel } \\
\text { responsible for the quality of } \\
\text { our work. }\end{array}$ & 3.63 & .581 & 3.40 & .744 & 1.580 & .118 \\
\hline $\begin{array}{l}\text { As employees, we contribute } \\
\text { to the achievement of quality } \\
\text { standards as much as it possible }\end{array}$ & 3.56 & .634 & 3.40 & .744 & 1.049 & .298 \\
\hline $\begin{array}{l}\text { Quality and quantity of work are } \\
\text { equally important. }\end{array}$ & 2.95 & .805 & 2.83 & .844 & .689 & .493 \\
\hline $\begin{array}{l}\text { Our departments have set clear } \\
\text { goals for standard and quality.* }\end{array}$ & 2.88 & .842 & 2.20 & .883 & 3.537 & .001 \\
\hline $\begin{array}{l}\text { We consider our co-workers } \\
\text { and other departments as our } \\
\text { appreciated customers. }\end{array}$ & 2.90 & .860 & 2.58 & .958 & 1.620 & .109 \\
\hline
\end{tabular}

The t-test results in Table 2 show that there is significant difference in appreciating employees' good job performance of leaders, dropping from 2.66 in 2013 to 2.25 in 2015 . That can indicate different views on job performance of employees and leaders. Problems can be in communication between top, middle and lower management, so that the demanding job performance is not presented to all employees as should be, resulting in unsatisfied employees and management.

Table 2. OC dimension Motivation and commitment in the regional unit of the National Institute of Public Health before (2013) and after (2015) reorganization

\begin{tabular}{|l|c|c|c|c|c|c|}
\hline \multirow{2}{*}{$\begin{array}{l}\text { 2. MOTIVATION AND } \\
\text { COMMITMENT }\end{array}$} & \multicolumn{2}{|c|}{$\begin{array}{c}\text { Before } \\
\text { reorganization }\end{array}$} & \multicolumn{2}{|c|}{$\begin{array}{c}\text { After } \\
\text { reorganization }\end{array}$} & \multirow{2}{*}{ T-test } & $\begin{array}{c}\text { Sig. } \\
\text { (2-tailed) }\end{array}$ \\
\cline { 2 - 6 } & Mean & SD & Mean & SD & & .280 \\
\hline $\begin{array}{l}\text { Everybody in our organization is } \\
\text { ready for additional effort if it is } \\
\text { necessary due to work. }\end{array}$ & 2.59 & 1.048 & 2.83 & .931 & -1.087 & .470 \\
\hline $\begin{array}{l}\text { We have high job performance } \\
\text { standards in our organization. }\end{array}$ & 2.85 & 1.014 & 2.70 & .883 & .727 & .623 \\
\hline $\begin{array}{l}\text { Employees in our organization } \\
\text { are committed to their work. }\end{array}$ & 3.10 & .664 & 3.18 & .747 & -.494 & .046 \\
\hline $\begin{array}{l}\text { In our organization, leaders } \\
\text { appreciate good job } \\
\text { performance.* }\end{array}$ & 2.66 & .855 & 2.25 & .954 & 2.031 & .046 \\
\hline $\begin{array}{l}\text { In our organization, good } \\
\text { working results are quickly } \\
\text { noticed and praised. }\end{array}$ & 2.02 & .935 & 1.73 & .751 & 1.587 & .117 \\
\hline
\end{tabular}

The t-test results in Table 3 show that there is significant difference in constant product and services improvement, dropping from 3.10 in 2013 to 2.58 in 2015. This is worrying, because innovativeness is something that gives an organization competitive advantage. Innovation and creativity 
in the public sector are nowadays even more of great importance due to current financial and economic crisis; therefore, countries should focus on prompting innovation (Setnikar Cankar \& Petkovšek, 2013). Unfortunately, a significant difference is found for expecting suggestions from everybody in organization from 3.17 in 2013 to 2.13 in 2015 and accepting mistakes during testing new ways of working from 2.68 in 2013 to 2.28 in 2015. It is clear that superiors are not open to any comments or suggestions, therefore it is not surprising that they are not accepting any mistakes during testing.

Table 3. OC dimension Innovativeness and initiative in the regional unit of the National Institute of Public Health before (2013) and after (2015) reorganization

\begin{tabular}{|c|c|c|c|c|c|c|}
\hline \multirow{2}{*}{$\begin{array}{l}\text { 3. INNOVATIVENESS AND } \\
\text { INITIATIVE }\end{array}$} & \multicolumn{2}{|c|}{$\begin{array}{l}\text { Before } \\
\text { reorganization }\end{array}$} & \multicolumn{2}{|c|}{$\begin{array}{c}\text { After } \\
\text { reorganization }\end{array}$} & \multirow{2}{*}{$\mathrm{T}$-test } & \multirow{2}{*}{$\begin{array}{l}\text { Sig. } \\
\text { (2-tailed) }\end{array}$} \\
\hline & Mean & SD & Mean & SD & & \\
\hline $\begin{array}{l}\text { Employees in our organization } \\
\text { are well aware of need for } \\
\text { change. }\end{array}$ & 2.93 & .848 & 2.78 & .733 & .861 & .392 \\
\hline $\begin{array}{l}\text { We are constantly improving } \\
\text { our products and services.* }\end{array}$ & 3.10 & .735 & 2.58 & .712 & 3.249 & .002 \\
\hline $\begin{array}{l}\text { In our organization is expected } \\
\text { to get suggestions for } \\
\text { improvements from everybody } \\
\text { - not only from our leaders.* }\end{array}$ & 3.17 & .863 & 2.13 & .791 & 5.682 & .000 \\
\hline $\begin{array}{l}\text { As employees, we are willing } \\
\text { to take risk to enforce our } \\
\text { initiative. }\end{array}$ & 2.51 & .952 & 2.53 & .716 & -.068 & .946 \\
\hline $\begin{array}{l}\text { Mistakes during testing new } \\
\text { ways of working are acceptable } \\
\text { in our organization.* }\end{array}$ & 2.68 & .907 & 2.28 & .877 & 2.058 & .043 \\
\hline
\end{tabular}

The t-test results in Table 4 show that there is significant difference in superiors' openness to sound comments about their work with alarmingly second biggest drop from 2.56 in 2013 to 1.80 in 2015. That can indicate fear among superiors after reorganization was done, predicting that the process is not over yet and there is going to be downsizing. If that is not the case, they are just too arrogant or too afraid of complaints from their subordinates, and they do not want that their superiors will find it out. 
Comparison of Organizational Climate in the Regional Unit of the National Institute of Public Health Before and After Reorganization

Table 4. OC dimension Leadership in the regional unit of the National Institute of Public Health before (2013) and after (2015) reorganization

\begin{tabular}{|c|c|c|c|c|c|c|}
\hline \multirow{2}{*}{ 4. LEADERSHIP } & \multicolumn{2}{|c|}{$\begin{array}{l}\text { Before } \\
\text { reorganization }\end{array}$} & \multicolumn{2}{|c|}{$\begin{array}{l}\text { After } \\
\text { reorganization }\end{array}$} & \multirow[t]{2}{*}{ T-test } & \multirow{2}{*}{$\begin{array}{l}\text { Sig. } \\
\text { (2-tailed) }\end{array}$} \\
\hline & Mean & SD & Mean & SD & & \\
\hline $\begin{array}{l}\text { Employees are independent at } \\
\text { work. }\end{array}$ & 3.17 & .738 & 2.90 & .778 & 1.607 & .112 \\
\hline $\begin{array}{l}\text { Leaders are communicating } \\
\text { with subordinates about work } \\
\text { results. }\end{array}$ & 2.88 & .872 & 2.55 & .783 & 1.781 & .079 \\
\hline $\begin{array}{l}\text { Leaders are encouraging us to } \\
\text { take more responsibilities for } \\
\text { our work. }\end{array}$ & 2.63 & .994 & 2.45 & 1.061 & .806 & .422 \\
\hline $\begin{array}{l}\text { In our organization, we are } \\
\text { eliminating bossy leadership. }\end{array}$ & 2.63 & .968 & 2.38 & .979 & 1.198 & .235 \\
\hline $\begin{array}{l}\text { Superiors are open to sound } \\
\text { comments about their work.* }\end{array}$ & 2.56 & .976 & 1.80 & .911 & 3.625 & .001 \\
\hline
\end{tabular}

The t-test results in Table 5 show that there is significant difference in how proud employees are to be employed in this organization, dropping from 3.22 in 2013 to 2.65 in 2015. It is connected with organization's big reputation in the area with significant difference dropping from 3.07 in 2013 to 2.63 in 2015 and with alarming drop of employees' decision to leave the organization due to decrease payment because of business problems from 2.46 in 2013 to 1.78 in 2015.

Table 5. OC dimension Organization affiliation in the regional unit of the National Institute of Public Health before (2013) and after (2015) reorganization

\begin{tabular}{|l|c|c|c|c|c|c|}
\hline \multirow{2}{*}{ 5. ORGANIZATION AFFILIATION } & \multicolumn{2}{|c|}{$\begin{array}{c}\text { Before } \\
\text { reorganization }\end{array}$} & \multicolumn{2}{c|}{$\begin{array}{c}\text { After } \\
\text { reorganization }\end{array}$} & \multirow{2}{*}{ T-test } & \multirow{2}{*}{$\begin{array}{c}\text { Sig. } \\
\text { (2-tailed) }\end{array}$} \\
\cline { 2 - 7 } & Mean & SD & Mean & SD & & .336 \\
\hline $\begin{array}{l}\text { As employees, we talk about our } \\
\text { organization positively. }\end{array}$ & 3.17 & .738 & 3.00 & .847 & .968 & .000 \\
\hline $\begin{array}{l}\text { We are proud to be employed in } \\
\text { our organization.* }\end{array}$ & 3.22 & .571 & 2.65 & .802 & 3.689 & .004 \\
\hline $\begin{array}{l}\text { Our organization has a big } \\
\text { reputation in the area.* }\end{array}$ & 3.07 & .565 & 2.63 & .774 & 2.981 & .969 \\
\hline $\begin{array}{l}\text { Employment in our organization } \\
\text { is secure and ensured. }\end{array}$ & 2.29 & .844 & 2.30 & .853 & -.039 & .900 \\
\hline $\begin{array}{l}\text { Employees would not leave the } \\
\text { organization due to decrease in } \\
\text { payment because of business } \\
\text { problems.* }\end{array}$ & 2.46 & .925 & 1.78 & .768 & 3.641 & .000 \\
\hline
\end{tabular}

The t-test results in Table 6 show that there is significant difference in employees understanding what organization's expectations are about their work performance, dropping from 2.90 in 2013 to 2.40 in 2015. The lamentable t-test results show significant difference in employees' understanding of their place in organizational scheme, dropping from 3.10 in 2013 to 2.43 in 2015, defined assignments with average of 2.78 in 2013 dropped to 2.28 in 2015 and with alarming drop of leaders' decision-making on time from 2.37 in 2013 to 1.68 in 2015. 
Table 6. OC dimension Organization in the regional unit of the National Institute of Public Health before (2013) and after (2015) reorganization

\begin{tabular}{|c|c|c|c|c|c|c|}
\hline \multirow{2}{*}{ 6. ORGANIZATION } & \multicolumn{2}{|c|}{$\begin{array}{c}\text { Before } \\
\text { reorganization }\end{array}$} & \multicolumn{2}{c|}{$\begin{array}{c}\text { After } \\
\text { reorganization }\end{array}$} & \multirow{2}{*}{ T-test } & $\begin{array}{c}\text { Sig. } \\
\text { (2-tailed) }\end{array}$ \\
\cline { 2 - 6 } & Mean & SD & Mean & SD & & \\
\cline { 1 - 5 } $\begin{array}{c}\text { Employees have a clear idea } \\
\text { what are organization's } \\
\text { expectations about their work } \\
\text { performance.* }\end{array}$ & 2.90 & .860 & 2.40 & .982 & 2.451 & .016 \\
\hline $\begin{array}{c}\text { As employees, we understand } \\
\text { our place in organizational } \\
\text { scheme.* }\end{array}$ & 3.10 & .860 & 2.43 & .958 & 3.326 & .001 \\
\hline $\begin{array}{c}\text { We have clear defined } \\
\text { assignments in our } \\
\text { organization.* }\end{array}$ & 2.78 & .962 & 2.28 & .933 & 2.399 & .019 \\
\hline $\begin{array}{c}\text { Our leaders are making } \\
\text { decisions on time.* }\end{array}$ & 2.37 & .915 & 1.68 & .829 & 3.558 & .001 \\
\hline $\begin{array}{c}\text { Authorities and responsibilities } \\
\text { are balanced at all aspects of } \\
\text { organizations. }\end{array}$ & 2.22 & .909 & 1.85 & .770 & 1.973 & .052 \\
\hline
\end{tabular}

The t-test results in Table 7 show that there is significant difference in mutual learning among employees, dropping from 3.15 in 2013 to 2.65 in 2015. There is a significant difference in offered needed qualifications for good work performance for the employees from organization with dropping from 2.76 in 2013 to 2.25 in 2015. It is worrying that results show a significant difference in quality of qualification system with dropping average from 2.61 in 2013 to 2.05 in 2015 and that organization employs only qualified people with dropping average from 2.63 in 2013 to 2.05.

Table 7. OC dimension Professional qualification and learning in the regional unit of the National Institute of Public Health before (2013) and after (2015) reorganization

\begin{tabular}{|l|c|c|c|c|c|c|}
\hline \multirow{2}{*}{$\begin{array}{l}\text { 7. PROFESSIONAL } \\
\text { QUALIFICATION AND LEARNING }\end{array}$} & \multicolumn{2}{|c|}{$\begin{array}{c}\text { Before } \\
\text { reorganization }\end{array}$} & \multicolumn{2}{c|}{$\begin{array}{c}\text { After } \\
\text { reorganization }\end{array}$} & \multirow{2}{*}{ T-test } & $\begin{array}{c}\text { Sig. } \\
\text { (2-tailed) }\end{array}$ \\
\cline { 2 - 7 } & Mean & SD & Mean & SD & & .005 \\
\hline $\begin{array}{l}\text { As employees, we are learning } \\
\text { from each other.* }\end{array}$ & 3.15 & .654 & 2.65 & .864 & 2.920 & \\
\hline $\begin{array}{l}\text { Organization offers to } \\
\text { the employees needed } \\
\text { qualifications for good work } \\
\text { performance.* }\end{array}$ & 2.76 & .860 & 2.25 & .899 & 2.590 & .011 \\
\hline $\begin{array}{l}\text { Qualification system is good.* } \\
\text { We had employed only qualified } \\
\text { people.* }\end{array}$ & 2.61 & .891 & 2.05 & .749 & 3.056 & .003 \\
\hline $\begin{array}{l}\text { At professional qualifications, } \\
\text { employees' wishes are } \\
\text { considered. }\end{array}$ & 2.51 & .779 & 2.23 & .800 & 1.637 & .106 \\
\hline
\end{tabular}

The T-test results in Table 8 show that there is significant difference in organization's clear definition of mission, dropping from 2.80 in 2013 to 2.23 in 2015. We also found significant difference in understanding politics and organizational goals dropping the most among all statements from 2.66 in 2013 to 1.88 in 2015 and employees' exclusion when goals 
Comparison of Organizational Climate in the Regional Unit of the National Institute of Public Health Before and After Reorganization

are set with dropping average of 2.27 in 2013 to 1.73 in 2015. We assume that no explanations were done to all employees after the reorganization, resulting in the following numbers.

Table 8. OC dimension Mission, vision and goals in the regional unit of the National Institute of Public Health before (2013) and after (2015) reorganization

\begin{tabular}{|c|c|c|c|c|c|c|}
\hline \multirow{2}{*}{ 8. MISSION, VISION AND GOALS } & \multicolumn{2}{|c|}{$\begin{array}{c}\text { Before } \\
\text { reorganization }\end{array}$} & \multicolumn{2}{|c|}{$\begin{array}{c}\text { After } \\
\text { reorganization }\end{array}$} & \multirow{2}{*}{ T-test } & \multirow{2}{*}{$\begin{array}{c}\text { Sig. } \\
\text { (2-tailed) }\end{array}$} \\
\hline & Mean & SD & Mean & SD & & \\
\hline $\begin{array}{l}\text { Our organization has clear } \\
\text { defined mission - long-term } \\
\text { reason for existence and } \\
\text { working.* }\end{array}$ & 2.80 & .954 & 2.23 & .862 & 2.867 & .005 \\
\hline $\begin{array}{l}\text { As employees, we accept } \\
\text { organization's goals for our } \\
\text { goals. }\end{array}$ & 2.76 & .888 & 2.43 & .844 & 1.719 & .090 \\
\hline $\begin{array}{l}\text { Set goals, which we have to } \\
\text { accomplish, are achievable. }\end{array}$ & 2.63 & .968 & 2.35 & .802 & 1.436 & .155 \\
\hline $\begin{array}{l}\text { Politics and organizational } \\
\text { goals are understandable to all } \\
\text { employees.* }\end{array}$ & 2.66 & .911 & 1.88 & .516 & 4.746 & .000 \\
\hline $\begin{array}{l}\text { Goals are not set just by leaders, } \\
\text { other employees are also } \\
\text { included in decision-making.* }\end{array}$ & 2.27 & 1.001 & 1.73 & .751 & 2.759 & .007 \\
\hline
\end{tabular}

The t-test results in Table 9 show that we did not find any significant difference. It is rather interesting that we did not find any significant differences, even though there are drops in results. That indicates strong connection among employees, even in hard times, which can be a result of living in socialism, where the failure or success were public and individualism was something bad.

Table 9. OC dimension Internal relations in the regional unit of the National Institute of Public Health before (2013) and after (2015) reorganization

\begin{tabular}{|c|c|c|c|c|c|c|}
\hline \multirow{2}{*}{ 9. INTERNAL RELATIONS } & \multicolumn{2}{|c|}{$\begin{array}{l}\text { Before } \\
\text { reorganization }\end{array}$} & \multicolumn{2}{|c|}{ After rganization } & \multirow{2}{*}{ T-test } & \multirow{2}{*}{$\begin{array}{l}\text { Sig. } \\
\text { (2-tailed }\end{array}$} \\
\hline & Mean & SD & Mean & SD & & \\
\hline $\begin{array}{l}\text { In our organization, we } \\
\text { appreciate our co-workers' } \\
\text { work. }\end{array}$ & 2.83 & .803 & 2.58 & .874 & 1.364 & .176 \\
\hline $\begin{array}{l}\text { Relations between employees } \\
\text { are good. }\end{array}$ & 2.98 & .689 & 2.90 & .632 & .514 & .609 \\
\hline $\begin{array}{l}\text { In our organization, we more } \\
\text { collaborate then compete. }\end{array}$ & 2.92 & .850 & 2.85 & .736 & .395 & .694 \\
\hline $\begin{array}{l}\text { We solve conflicts for } \\
\text { everyone's benefit. }\end{array}$ & 2.71 & .898 & 2.55 & 1.011 & .740 & .462 \\
\hline People trust each other. & 2.53 & .830 & 2.23 & .920 & 1.517 & .133 \\
\hline
\end{tabular}

T-test results in Table 10 showed that there is significant difference in measuring employees' success by arranged goals and standard, dropping from 2.32 in 2013 to 1.80 in 2015 and inappropriateness of given penalties dropping from 2.11 in 2013 to 1.53 in 2015. If the goals and standards are not set, employees cannot reach them, so they are penalized. In our opinion 
the biggest problem is in the communication between the institute's management and employees. Use of vertical communication along with not paying attention to horizontal one is a common fault in public administration (Hintea, Ringsmuth, \& Mora, 2006).

Table 10. OC dimension Rewarding system in the regional unit of the National Institute of Public Health before (2013) and after (2015) reorganization

\begin{tabular}{|l|c|c|c|c|c|c|}
\hline \multirow{2}{*}{ 10. REWARDING SYSTEM } & \multicolumn{2}{|c|}{$\begin{array}{c}\text { Before } \\
\text { reorganization }\end{array}$} & \multicolumn{2}{c|}{$\begin{array}{c}\text { After } \\
\text { reorganization }\end{array}$} & \multirow{2}{*}{ T-test } & \multirow{2}{*}{$\begin{array}{c}\text { Sig. } \\
\text { (2-tailed) }\end{array}$} \\
\cline { 2 - 6 } & Mean & SD & Mean & SD & & \\
\cline { 1 - 6 } $\begin{array}{l}\text { Employees' success is measured } \\
\text { by arranged goals and } \\
\text { standards.* }\end{array}$ & 2.32 & 1.093 & 1.80 & .687 & 2.509 & .014 \\
\hline $\begin{array}{l}\text { If tasks are not done correctly, } \\
\text { appropriate penalty follows.* }\end{array}$ & 2.11 & .924 & 1.53 & .640 & 3.238 & .002 \\
\hline $\begin{array}{l}\text { As employees, we receive } \\
\text { payment, which is equal to } \\
\text { payments on market. }\end{array}$ & 2.03 & .972 & 1.88 & .853 & .732 & .467 \\
$\begin{array}{l}\text { Those with more tasks are } \\
\text { stimulated appropriately. }\end{array}$ & 1.45 & .724 & 1.35 & .662 & .620 & .537 \\
\hline $\begin{array}{l}\text { Proportions between } \\
\text { employees' payment are } \\
\text { appropriate. }\end{array}$ & 1.32 & .574 & 1.55 & .677 & -1.643 & .105 \\
\hline
\end{tabular}

The t-test results in Table 11 show that there is significant difference in regular working meeting, dropping from 2.95 in 2013 to 2.43 in 2015. If we have a bad communication and we are not willing to sound comments about our work as leaders, it is obvious that we are not interested in meetings every week, because people do not want to hear a lot about their mistakes.

Table 11. OC dimension Internal communication and informing in the regional unit of the National Institute of Public Health before (2013) and after (2015) reorganization

\begin{tabular}{|c|c|c|c|c|c|c|}
\hline \multirow{2}{*}{$\begin{array}{l}\text { 11. INTERNAL } \\
\text { COMMUNICATION AND } \\
\text { INFORMING }\end{array}$} & \multicolumn{2}{|c|}{$\begin{array}{c}\text { Before } \\
\text { reorganization }\end{array}$} & \multicolumn{2}{|c|}{$\begin{array}{c}\text { After } \\
\text { reorganization }\end{array}$} & \multirow{2}{*}{ T-test } & \multirow{2}{*}{$\begin{array}{c}\text { Sig. } \\
\text { (2-tailed) }\end{array}$} \\
\hline & Mean & SD & Mean & SD & & \\
\hline Working meetings are regular.* & 2.95 & .899 & 2.43 & 1.010 & 2.408 & .018 \\
\hline $\begin{array}{l}\text { In our organization, leaders } \\
\text { and employees have relaxed, } \\
\text { friendly in equally conversation. }\end{array}$ & 2.84 & .886 & 2.83 & .712 & .094 & .925 \\
\hline $\begin{array}{l}\text { Our superiors give us enough } \\
\text { information for doing our job } \\
\text { correctly. }\end{array}$ & 2.55 & 1.032 & 2.75 & .776 & -.958 & .341 \\
\hline $\begin{array}{l}\text { Leaders are passing information } \\
\text { to their employees in } \\
\text { understandable way. }\end{array}$ & 2.84 & 1.079 & 2.63 & .838 & .996 & .323 \\
\hline $\begin{array}{l}\text { We receive enough information } \\
\text { about happenings in other units. }\end{array}$ & 1.89 & .994 & 1.55 & .677 & 1.775 & .080 \\
\hline
\end{tabular}

The t-test results in Table 12 show that there is significant difference in raising successors by our leaders, dropping from 1.71 in 2013 to 1.20 in 2015 with the lowest average among all statements. Raising successors is a big responsibility and also a duty, if we want to continue working when 
we are not going to be around. There should be always more candidates competing for one working place, to be insured in case of turnover, disease, death or employee's bad job performance.

Table 12. OC dimension Career development in the regional unit of the National Institute of Public Health before (2013) and after (2015) reorganization

\begin{tabular}{|l|c|c|c|c|c|c|}
\hline \multirow{2}{*}{ 12. CAREER DEVELOPMENT } & \multicolumn{2}{|c|}{$\begin{array}{c}\text { Before } \\
\text { reorganization }\end{array}$} & \multicolumn{2}{c|}{$\begin{array}{c}\text { After } \\
\text { reorganization }\end{array}$} & \multirow{2}{*}{ T-test } & $\begin{array}{c}\text { Sig. } \\
\text { (2-tailed) }\end{array}$ \\
\cline { 2 - 6 } & Mean & SD & Mean & SD & & \\
\cline { 1 - 6 } $\begin{array}{l}\text { As employees, we are pleased } \\
\text { with our personal development } \\
\text { up to this point. }\end{array}$ & 2.38 & .861 & 2.00 & .847 & 1.942 & .056 \\
\hline $\begin{array}{l}\text { Promotion's criteria are clear to } \\
\text { everyone. }\end{array}$ & 2.14 & .855 & 2.00 & 1.062 & .612 & .542 \\
\hline $\begin{array}{l}\text { Employees at all levels have } \\
\text { realistic chances for promotion. }\end{array}$ & 1.62 & .828 & 1.63 & .807 & -.018 & .986 \\
\hline $\begin{array}{l}\text { Our leaders are raising } \\
\text { successors.* }\end{array}$ & 1.71 & .926 & 1.20 & .516 & 3.019 & .003 \\
\hline $\begin{array}{l}\text { We have promotion system, } \\
\text { which enables to the best } \\
\text { employees to take the best } \\
\text { positions. }\end{array}$ & 1.44 & .773 & 1.43 & .636 & .120 & .905 \\
\hline
\end{tabular}

\section{Discussion and Implications}

Employees are bio-cultural and social beings (Bakir Arabacl, 2010) and on day-to-day basis, their interaction with the organization, its structures and processes create the attitudes, feelings and behaviours that constitute the climate (Arvidsson, Johansson, Ek, \& Akselsson, 2006). Due to that fact, leaders should be in constant contact between each other and their subordinates. They have to have insight on quotidian process, procedures and interactions, which can affect employees or their behaviour. Our research question was if the OC has been improved after reorganization in the regional unit of the National Institute of Public Health? According to our results, almost no improvement was done, expecting few statements where we did not find significant difference. That indicates lack of collaboration between leaders and their employees, which is necessary for quality implementation of any change of system. Results show that the employees have lack of trust and their not-involvement in the process of the reorganization has clearly influenced their perspective of the organization. We can conclude that there should be more significant involvement of employees in the process of reorganization and also more significant involvement of management which should be more collaborative with employees before the process starts, during and after when it has been finished.

Research has shown that $\mathrm{OC}$ is often considered as an effective element for motivation, attitude and job satisfaction, but managers do not pay much attention to it. Despite the increasing agreement of its importance, there is still an on-going debate on how the concept should be defined and measured, although it is one of the organization's basics (Alipour, 2011; Hannevik, Lone, 
Bjørklund, Bjørkli, \& Hoff, 2014). In our case, it has been clearly shown that neglecting results of OC measurements leads to less satisfied employees, which has already affected their motivation for work and will also affect their attitude towards work in a long run, if leader's approach will not be changed. OC can be helpful for performance monitoring, assessment and for identifying areas of improvement; companies should focus on internal environment and organizational processes which are influenced by economic conditions nowadays, because by striving for implementing necessary changes and motivating employees they have to stand out performance with limited resources or/and limited staff at the same time (Koles \& Kondath, 2015).

The first step after getting measurements is identification of problematic areas; the second step is even more important, because at that point, leaders should make a task list, which should be improved till specified due date, so we can track progress. All employees have to be involved in those activities and mixed teams of leaders and their subordinates should be formed to improve targeted problematic areas on account of different perspective. Acting like this would improve exchanging of ideas within personnel and management along with improvement of difficulties with suggesting to superiors and commenting their work if necessary. We found out that internal environment is good according to dimensions of internal communication and informing together with internal relations which should be a good foundation for the process of reorganization. Due to importance of OC, managers should consistently observe it. Appropriate OC causes innovations and inspiration and has a positive influence on attaining organizational goals (Bahrami, Barati, Ghoroghchian, Montazer-alfaraj, \& Ezzatabadi, 2016).

A significant drop in constant improvement of products and services is worrying since it is highly important in today's competitive world. If the employees' innovativeness is not encouraged, the organization will be stagnating and its competitiveness will drop significantly, potentially causing job turnover and losing qualified workers. Surveys for analysing OC have been recommended and widely described over a last three decades, helping to asses organization's performance, comparing performance against other organizations and evaluating relationship between work practice and outcomes (Dawson, Gonzalez-Roma, Davis, \& West, 2008). Nevertheless, analysis has no value if results are not taken in consideration and are not used to improve problematic areas. Analysis should be done by professionals, however many organizations make them by themselves due to costs and often they falsify collected data. Acting this way can completely devalue OC analysis. Managers should pay attention to their employees' experience and the environment they work in to make sure that there is alignment between desired OC and organizational objectives (Eustace \& Martins, 2014).

Managers have to set achievable goals with due date and prioritize them so that they can track progress and tasks done or tasks which should have been done. Because of that, they need to analyse their perception of OC frequently 
and take requisite measures to rectify any misperception (Eustace \& Martins, 2014). Generally, measurements are done once a year in specific time, yet employees' perception can differ in different times of the year. It can be affected by several of circumstances, such as year ending, personal problems or problems within organization, being new to the job or any factors, which can influence employees' behaviour, attitude and motivation. Assessment approaches can include filed studies, measurements of employees' perceptions of organization, observation of objective organizational properties and experimental variations in organizational properties (Eustace \& Martins, 2014).

OC depends on organization's wishes and how they are going to use results. If they are planning a project team, they can either measure employees' compatibility by validated measurements or experiment by observing them, if they have enough time and resources. An organization should combine as much approaches as possible to get the most optimal insight in their employees' perceptions and behaviour. Relating OC, the influence of organizational factors on organizational goals has been identified; they have a big impact on employees' attitudes, performance, work motivation, work engagement and work satisfaction (Schyns, Van Veldhoven \& Wood, 2009). OC will have significant role in shaping employees' behaviour and positive impact on performance and other outcomes (Chen \& Lin, 2004; Long, 2000; Sveiby \& Simons, 2002; Dawson et al., 2008). Every individual within the organization has his own anticipations of attributes that narrate the overall pattern of organizational activities in the concept of OC, which represents the multi-dimensional work environment with presumed influence on personal motivation and behaviour (Jaw \& Liu, 2003; Kaya, Koc \& Topcu, 2010).

We are aware that is impossible to employ people whose values and attitudes are completely in accordance with organization's values and attitudes, nonetheless both sides should try to have quality relationship and satisfying outcomes for which they are looking for. Bearing in mind diversity of employees, with proper procedures and motivation we can establish a strong connection between them and organization, resulting in successful employees and successful organization. In an organization with a supportive climate we can identify positive behaviours, employees' identification with it and it enhance positive relationships, work environment and satisfaction; if climate is not supportive, employees recognize it as irritating, dissatisfying and incline to commit counterproductive behaviours (Kanten \& Ülker, 2013; Licciardello, Di Marco, \& Mauceri, 2013; Taştana \& Güçel, 2014). The biggest fear organization can have is turning the dissatisfied employees against, which can lead to internal relationship problems, poor product and customer service, job turnovers and bad reputation among competition as well as in local area. 
Employees' productivity and satisfaction depend on support given by their organization (Shih, Lie, Klein, \& Jiang, 2014). Therefore, it is leaders' duty to be a role model to their employees. He should be motivating them, helping them and/or punishing them if needed. OC generates a cyclical system of positive feedback: employees who highly care about customers' opinion are constantly considering how to improve their services and maximize customers' satisfaction, and by their positive experience customers are inclined to give back positive opinions, which effects employees' behaviour and work experiences (Lin \& Lin, 2011).

Management has a very important role in influencing and shaping the climate to get the most out of the human capital, which will strongly affect whole organizations and outcomes (Arvidsson et al., 2006; Hannevik et al., 2014). Management should be supportive and cooperative with employees regardless of their ranks showing respect for everybody and making them feel appreciated. We cannot have harmony among our employees, if management misconceives their own role: leading their employees and being a role model to them. In order to meet the new conditions and successfully adapt to the future changes, the organization has to present novelties to every employee, so that he will be able to cope with new demands of the new OC (Arvidsson et al., 2006; Jordan, 2014). It has to be done publicly, so that anybody can reply to proposed changes and play a part in their implementation. By contributing to the organization, employees feel more loyal and they are proud of being employed in the organization.

If we want to manage changes correctly and have a successful organization in today's ruthless environment, we need a change agent whose knowledge about trends in business is up to date to provide customers the newest products and services, which is necessary for successfulness (Iljins, Skvarciany, \& Gaile-Sarkane, 2015). Changes are always diffucult and demand professionals to cope with them for optimal result. Our study focuses on reorganization, which is a huge change for organization, not mentioning how stressful it is. Because of this, the organization should find an expert with successful history dealing with the process of reorganization, to prepare employees and organization itself for coming events. With that approach, the results of OC in the regional unit of The National Institute of Public Health would be definitely better than results are showing; they could be even improved.

To achieve organizational goals, the analysis of organizational climate should ease strategic plan implementations to advertise environmental changes, increase job satisfaction, professional development, efficiency and quality results (Garcia-Garcia, Benitez Ramos, Cobos Serrano, Ramos Cobos, \& Souza, 2011). Organizations should not just monitor their OC, they should take advantage of the results to add selected steps to their yearly plan. They should put an extra effort to improve OC dimensions, which did not reach their minimum level and continue with dimensions, which were assessed satisfactorily. OC has a big significance in comprehension how an organization 
works and creates values; consequently, we can conclude that it can have a significant positive or negative effect on an organization and its performance (Carlucci \& Schiuma, 2012, 2014).

Our study indicates a high importance of measuring $\mathrm{OC}$ in public institutions before and after reorganization. Employees in the public sector need an optimal OC (Creta \& Şandor, 2011), as do all employees. There is a variety of different employees with different perceptions about their work, which makes measuring even more important. When you face a process as stressful as reorganization, you should pay attention to OC since it can reveal atmosphere before such a big project. The results have shown that OC was at average level before reorganization, when dimensions relating reward system and career development were worst assessed (Jordan, Miglič, \& Pintar, 2016). Even though the management had been informed about the situation, no improvements were made. We measured OC right after the process was finished and results have shown a decrease in all statements after the t-test was done. That indicates the great importance of preparing employees and management for forthcoming changes, explaining them the whole process, so they would not feel like they are not a part of the organization.

For further research, we recommend to explore OC relating to other constructs, such as organizational outcomes, ethical climate, organizational commitment, job satisfactions and psychological empowerment in organizations and within the organizations' departments if they are large enough. We also recommend comparison with other organizations in Slovenia and abroad. 
Gašper Jordan, MSc is a researcher who has studied in the field of human resource management at the University of Maribor's Faculty of Organizational Sciences. His main interests are human resource management, organizational behaviour and organizational psychology.

Gozdana Miglič, PhD received her PhD in sociological sciences at the Faculty of Social Sciences, University of Ljubljana. From 2009, she has been a lecturer at the Faculty of Organizational Sciences, University of Maribor. She is the author and coauthor of several monographs and handbooks, numerous articles and conference papers, published in national and international journals. Her research is focused on human resource management, e.g. competencies models, recruitment, selection, training, career planning, organizational behaviour.

Miha Marič, PhD is a researcher in the area of leadership, management, and organizational sciences. He is currently employed as an assistant professor at the University of Maribor's Faculty of Organizational Sciences and has a PhD from the Faculty of Economics, University of Ljubljana. His research interests are power, leadership, organizational behaviour, HRM, management, organization. As author or co-author, he has published several original scientific articles, professional articles, scientific conference contributions, two chapters in monographs and co-authored one scientific monograph, and been an editor and reviewer. He has also participated in research projects and consulting work. 
Comparison of Organizational Climate in the Regional Unit of the National Institute of Public Health Before and After Reorganization

\section{References}

Açıkgöz, A., \& Günsel, A. (2011). The effects of organizational climate on team innovativeness. Procedia - Social and Behavioral Sciences, 24, 920-927. doi:10.1016/j.sbspro.2011.09.102

Alipour, F. H. (2011). The relationship between organizational climate and communication skills of managers of the Iranian physical education organization. Procedia - Social and Behavioral Sciences, 30, 421-428. doi:10.1016/j.sbspro.2011.10.083

Ancarani, A., Di Mauro, C., \& Giammanco, M. D. (2009). How are organisational climate models and patient satisfaction related? A competing value framework approach. Social Science and Medicine, 69(12), 1813-1818. doi:10.1016/j.socscimed.2009.09.033

Arvidsson, M., Johansson, C. R., Ek, Å., \& Akselsson, R. (2006). Organizational climate in air traffic control: Innovative preparedness for implementation of new technology and organizational development in a rule governed organization. Applied Ergonomics, 37(2), 119-129. doi:10.1016/j.apergo.2005.06.005

Bahrami, M. A., Barati, O., Ghoroghchian, M. S., Montazer-alfaraj, R., \& Ezzatabadi, M. R. (2016). Role of Organizational Climate in Organizational Commitment: The Case of Teaching Hospitals. Osong Public Health and Research Perspectives, 7(2), 96-100. doi:10.1016/j.phrp.2015.11.009

Bakir Arabacı, I. (2010). Academic and administration personnel's perceptions of OC (Sample of Educational Faculty of Firat University). Procedia - Social and Behavioral Sciences, 2(2), 4445-4450. doi:10.1016/j.sbspro.2010.03.709

Barbera, K. M., \& Schneider, B. (2014). The Oxford Handbook of Organizational Climate and Culture. Oxford Library of Psychology, Oxford university press. doi:10.1093/oxfordhb/9780199860715.001.0001

Benzer, J. K., Young, G., Stolzmann, K., Osatuke, K., Meterko, M., Caso, A., White, B., \& Mohr, D. C. (2011). The relationship between organizational climate and quality of chronic disease management. Health Services Research, 46(3), 691-711. doi:10.1111/j.1475-6773.2010.01227.x

Bergant, A. (1996). Reorganizacija (pojem in zlorabe). Revija za management, informatiko in kadre, 29(7), 442-443.

Biro Praxis. (2013). Kaj je SiOK? Retrieved 1. 10. 2015, from http://www.biropraxis.si/kaj-je-siok.html

Boštjančič, E. (2010). Job satisfaction, life orientation and perception of family role - Comparison between women employed in public sector and in economy. International Public Administration Review, 8(3), 89-111.

Cafferkey, K., \& Dundon, T. (2015). Explaining the black box: HPWS and organisational climate. Personnel Review, 44(5), 666-688. doi:10.1108/PR-12-2012-0209

Carlucci, D., \& Schiuma, G. (2012). Evaluating organisational climate through IC lens: the case of a public hospital. Measuring Business Excellence, 16(4), 79-90. doi:10.1108/13683041211276465

Carlucci, D., \& Schiuma, G. (2014). Organizational Climate as Performance Driver: Health Care Workers' Perception in a Large Hospital. Journal of Health Management, 16(4), 583-594. doi:10.1177/0972063414548561 
Castro, M. L., \& Martins, N. (2010). The relationship between organizational climate and employee satisfaction in a South African information and technology organization. South African Journal of Industrial Psychology, 36(1), 1-9. doi:10.4102/sajip.v36i1.800

Çekmecelioğlu, H. G., \& Günsel, A. (2013). The effects of individual creativity and Organizational Climate on firm innovativeness. Procedia-Social and Behavioral Sciences, 99, 257-264. doi:10.1016/j.sbspro.2013.10.493

Ceyda, G., \& Sevinc, P. (2012). Determination of high schools organizational climate. Procedia - Social and Behavioral Sciences, 46, 2947-2950. doi:10.1016/j.sbspro.2012.05.595

Chen, C. (2004). The effects of knowledge attribute, alliance characteristics, and absorptive capacity on knowledge transfer performance. R\&D Management, 34(3), 311-321. doi:10.1111/j.1467-9310.2004.00341.x

Coetzee, M., \& Stoltz, E. (2015). Employees' satisfaction with retention factors: Exploring the role of career adaptability. Journal of Vocational Behavior, 89, 83-91. doi:10.1016/j.jvb.2015.04.012

Creta, S. C., \& Şandor, S. D. (2011). Analysis of the Public Servants' Needs. Case Study: Romania, the North-West Region. Transylvanian Review of Administrative Sciences, 7(32), 37-49. Retrieved from http://rtsa.ro/tras/ index.php/tras/article/view/255

D'Alleo, G., \& Santangelo, A. (2011). Organizational climate and burnout in callcenter operators. Procedia - Social and Behavioral Sciences, 30, 1608-1615. doi:10.1016/j.sbspro.2011.10.312

Dawson, J.F., Gonzalez-Roma, V., Davis, A., \& West, M. A. (2008). Organizational climate and climate strength in UK hospitals. European Journal of Work and Organizational Psychology, 17(1), 89-111. doi:10.1080/13594320601046664

Draškovič, U., \& Erjavšek, B. (2009). Kako ravnati, da bo organizacijska klima delovala v smer, v katero želimo. Revija HRM, 31. Retrieved 31. 10. 2015, from http://hrm-storitve.si/clanki/analiza-stanja/orodja-za-ustvarjanjeorganizacijske-klime/

Drašler, S., \& Boštjančič, E. (2015). Vloga plače pri motiviranosti in zavzetosti zaposlenih na izbranem ministrstvu v Sloveniji. International Public Administration Review, 13(2), 101-117. doi:10.17573/ipar.2015.2.05

Ehrhart, M. G., \& Kuenzi, M. (2015). Organizational Climate in the Work Setting. International Encyclopedia of the Social and Behavioral Sciences (Second Edition), 327-333. doi:10.1016/B978-0-08-097086-8.22016-3

Eustace, A., \& Martins, N. (2014). The role of leadership in shaping organisational climate: An example from the fast moving consumer goods industry. South African Journal of Industrial Psychology, 40(1), 1-13. doi:10.4102/sajip. v40i1.1112

Fleancu, J. L. (2014). Aspects regarding the correlation between the level of information and the work satisfaction within the University Education of Physical Training and Sport of Pitesti. Procedia-Social and Behavioral Sciences, 180, 1253-1256. doi:10.1016/j.sbspro.2015.02.260

Garcia-Garcia, I., Benitez Ramos, V., Cobos Serrano, J. L., Ramos Cobos, M. C., \& Souza, A. (2011). Nursing personnel's perceptions of organizational climate in public and private hospitals in Spain. International Nursing Review, 58(2), 234-241. doi:10.1111/j.1466-7657.2010.00871.x 
Comparison of Organizational Climate in the Regional Unit of the National Institute of Public Health Before and After Reorganization

Glisson, C., Hemmelgarn, A., Green, P., Dukes, D., Atkinson, S., \& Williams, N. J. (2012). Randomized trial of the availability, responsiveness, and continuity (ARC) organizational intervention with community-based mental health programs and clinicians serving youth. Journal of the American Academy of Child and Adolescent Psychiatry, 51(8), 780-787.

doi:10.1016/j.jaac.2012.05.010

Hannevik, M. B., Lone, J. A., Bjørklund, R., Bjørkli, C. A., \& Hoff, T. (2014).

Organizational climate in large-scale projects in the oil and gas industry: A competing values perspective. International Journal of Project Management, 32(4), 687-697. doi:10.1016/j.ijproman.2013.08.006

Hashim, H., Ishak, N. A., \& Hilmi, Z. Ab. G. (2015). Influence of organizational climate on Disabled Job Embeddedness. Procedia - Social and Behavioral Sciences, 202, 242-251. doi:10.1016/j.sbspro.2015.08.228

Heyart, B. (2011). The role of organizational climate and culture in service encounters (PhD). Michigan: Wayne State University. Retrieved 4. 10. 2016, from http://digitalcommons.wayne.edu/cgi/viewcontent. cgi?article $=1239 \&$ context $=0$ a_dissertations

Hintea, C., Ringsmuth, D., \& Mora, C. (2006). The reform of the higher education public administration programs in the context of public administration reform in Romania. Transylvanian Review of Administrative Sciences, 2(16), 40-46. Retrieved from http://rtsa.ro/tras/index.php/tras/article/view/227

Iljins, J., Skvarciany, V., \& Gaile-Sarkane, E. (2015). Impact of Organizational Culture on Organizational Climate during the Process of Change. ProcediaSocial and Behavioral Sciences, 213, 944-950.

doi:10.1016/j.sbspro.2015.11.509

Imran, R., Saeed, T., Anis-Ul-Haq, M., \& Fatima, A. (2010). Organizational climate as a predictor of innovative work behavior. African Journal of Business Management, 4(15), 3337-3343. Available at http://www.academicjournals. org/journal/AJBM/article-full-text-pdf/5AF578E20839

Isaksen, S. G., \& Lauren, K. J. (1999). Relationship between cognitive style and individual psychological climate: Reflections on a previous study. Studia Psychologica, 41(3), 177-191.

James, L. R., Choi, C. C., Ko, C. E., McNeil, P. K., Minton, M. K., Wright, M. A., \& Kim, K. (2008). Organizational and psychological climate: A review of theory and research. European Journal of Work and Organizational Psychology, 17(1), 5-32. doi:10.1080/13594320701662550

Jaw, B.-S., \& Liu, W. (2003). Promoting organizational learning and self-renewal in Taiwanese companies: The role of HRM. Human Resource Management, 42(3), 223-241. doi:10.1002/hrm.10082

Jordan, G. (2014). Organizacijsko vzdušje pred reorganizacijo v Zavodu za zdravstveno varstvo x (BSc). Kranj: University of Maribor. Retrieved 17. 4. 2016, from https://dk.um.si/Dokument.php?id=65064

Jordan, G., Miglič, G., \& Pintar, R. (2016). Organizacijsko vzdušje pred reorganizacijo v območni enoti Zavoda za zdravstveno varstvo. 35th International Conference on Organizational Science Development. Portorož: Fakulteta za organizacijske vede.

Kallestad, J. K. (2010). Changes in school climate in a long-term perspective. Scandinavian Journal of Educational Research, 54(1), 1-14. doi:10.1080/00313830903488429 
Kanten, P., \& Ülker, F. E. (2013). The effect of organizational climate on counterproductive behaviors: An empirical study on the employees of manufacturing enterprises. The Macrotheme Review, 2(4), 144-160. Retrieved 17.4.2016, from http://citeseerx.ist.psu.edu/viewdoc/download?doi=10.1.1.4 26.9988\&гер=гер $1 \&$ type $=p d f$

Kaya, N., Koc, E., \& Topcu, D. (2010). An exploratory analysis of the influence of human resource management activities and organizational climate on job satisfaction in Turkish banks. The International Journal of Human Resource Management, 21(11), 2031-2051. doi:10.1080/09585192.2010.505104

Koles, B., \& Kondath, B. (2013). Organizational climate in Hungary, Portugal, and India: a cultural perspective. Al \& Society, 30(2), 251-259. doi:10.1007/s00146-013-0507-6

Licciardello, O., Di Marco, G., \& Mauceri, M. (2013). Motivations and Perceived Organizational Climate Among Volunteers of Italian Red Cross. ProcediaSocial and Behavioral Sciences, 84, 584-588. doi:10.1016/j.sbspro.2013.06.608

Lin, J. S. J., \& Lin, S. C. (2011). Moderating effect of organizational climate on the relationship of organizational support and service-oriented organizational citizenship behaviors. African Journal of Business Management, 5(2), 582-595. Available at: http://www.academicjournals.org/journal/AJBM/article-full-textpdf/6CA8E0D17033

Liou, S. R., \& Cheng, C. Y. (2010). Organisational climate, organisational commitment and intention to leave amongst hospital nurses in Taiwan. Journal of Clinical Nursing, 19(11-12), 1635-1644. doi:10.1111/j.1365-2702.2009.03080.x

Long, D. (2000). Diagnosing cultural barriers to knowledge management. The Academy of Management Executive, 14(4), 113-128. doi:10.5465/AME.2000.3979820

McMurray, A. J., Pirola-Merlo, A., Sarros, J. C., \& Islam, M. M. (2010). Leadership, climate, psychological capital, commitment, and Wellbeing in a non-profit organization. Leadership and Organization Development Journal, 31(5), 436457. doi:10.1108/01437731011056452

Meyer, J. P., \& Allen, N. J. (1993). Commitment to organization and occupations: Extension of a three- omponent model. Journal of Applied Psychology, 78(4), 538-551. doi:10.1037/0021-9010.78.4.538

Mihalič, R. (2007). Upravljajmo organizacijsko kulturo in klimo. Škofja Loka: Mihalič in Partner d.n.o.

Mohammadi, A., \& Youzbashi, A. (2012). Investigation Relationship of schools organization climate withjob stress among physical education teachers. Procedia-Social and Behavioral Sciences, 47, 138-140. doi:10.1016/j.sbspro.2012.06.627

OCR svetovanje in raziskave. (2013). Retrieved 1. 10. 2015, from http://www.ocr. si/

Organ, D. W., Podsakoff, P. M., \& MacKenzie, S. B. (2006). Organizational Citizenship Behavior: Its Nature, Antecedents, and Consequences. Thousand Oaks, CA: Sage Publications.

Permarupan, P. Y., Saufi, R. A., Kasim, R. S. K., \& Balakrishnan, B. (2013). The Impact of Organizational Climate on Employee's Work Passion and Organizational Commitment. Procedia-Social and Behavioral Sciences, 107, 88-95. doi:10.1016/j.sbspro.2013.12.403 


\section{Comparison of Organizational Climate in the Regional Unit of the National Institute of Public Health Before and After Reorganization}

Pyman, A., Holland, P., Teicher, J., \& Cooper, B. K. (2010). Industrial Relations Climate, Employee Voice and Managerial Attitudes to Unions: An Australian Study. British Journal of Industrial Relations, 48(2), 460-480. doi:10.1111/j.1467-8543.2009.00772.x

Rusu, G., \& Avasilcai, S. (2014). Linking human resources motivation to organizational climate. Procedia - Social and Behavioral Sciences, 124, 51-58. doi:10.1016/j.sbspro.2014.02.459

Samad, S. (2010). The role of creative organizational climate on learning organization-A key component of knowledge management. Second International Conference on Computer Engineering and Applications, IEEE 2010, (pp. 404-409). doi:10.1109/ICCEA.2010.229

Saungweme, R., \& Gwandure, C. (2011). Organisational Climate and Intent to Leave among Recruitment Consultants in Johannesburg, South Africa. Journal of Human Ecology, 34(3), 145-153. Retrieved 8. 6. 2016, from http:// www.krepublishers.com/02-Journals/JHE/JHE-34-0-000-11-Web/JHE-343-000-11-Abst-PDF/JHE-34-3-145-11-2183-Saungwem-R/JHE-34-3-145-112183-Saungwem-R-Tt.pdf

Schneider, B., Ehrhart, M. G., \& Macey, W. H. (2012). Organizational Climate and Culture. The annual review of Psychology, 64(1), 361-388. doi:10.1146/annurev-psych-113011-143809

Schneider, B., Salvaggio, A. N., \& Subirats, M. (2002). Climate strength: a new direction for climate research. Journal of Applied Psychology, 87(2), 220-229. doi:10.1037/0021-9010.87.2.220

Schulte, M., Ostroff, C., \& Kinicki, A. J. (2006). Organizational climate systems and psychological climate perceptions: A cross-level study of climate-satisfaction relationships. Journal of Occupational and Organizational Psychology, 79(4), 645-671. doi:10.1348/096317905X72119

Schyns, B., Van Veldhoven, M., \& Wood, S. (2009). Organizational climate, relative psychological climate and job satisfaction: The example of supportive leadership climate. Leadership and Organization Development Journal, 30(7), 649-663. doi:10.1108/01437730910991664

Seghieri, C., Rojas, D., \& Nuti, S. (2014). Are there gender differences in how managers and professionals perceived organizational climate? The case of Tuscan healthcare system. Suma de Negocios, 6(13), 8-16. doi:10.1016/j.sumneg.2015.04.002

Setnikar Cankar, S., \& Petkovšek, V. (2013). Private and public sector innovation and the importance of cross-sector collaboration. Journal of Applied Business Research, 29(6), 1597-1606. doi:10.19030/jabr.v29i6.8197

Shih, S., Lie, T., Klein, G., \& Jiang, J. J. (2014). Information technology customer aggression: The importance of an organizational climate of support. Information and Management, 51(6), 670-678. doi:10.1016/j.im.2014.06.001

Sokol, A., Gozdek, A., Figurska, I., \& Blaskova, M. (2015). Organizational climate of higher education institutions and its implications for the development of creativity. Procedia - Social and Behavioral Sciences, 182, 279-288. doi:10.1016/j.sbspro.2015.04.767

Soriano, D. R. (2012). Change management in the entrepreneurial LatinAmerican organizations: an overview. Journal of Organizational Change Management, 25(5), 653-656. doi:10.1108/09534811211254554

Sveiby, K. E., \& Simons, R. (2002). Collaborative climate and effectiveness of knowledge work - An empirical study. Journal of Knowledge Management, 6(5), 420-433. doi:10.1108/13673270210450388 
Taştan, S. B., \& Güçel, C. (2014). Explaining intrapreneurial behaviors of employees with perceived organizational climate and testing the mediating role of organizational identification: A research study among employees of Turkish innovative firms. Procedia - Social and Behavioral Sciences, 150, 862871. doi:10.1016/j.sbspro.2014.09.095

Thumin, F. J., \& Thumin, L. J. (2011). The Measurement and Interpretation of Organizational Climate. The Journal of Psychology, 145(2), 93-109. doi:10.1080/00223980.2010.538754

Torka, N., Schyns, B., \& Looise, J. K. (2010). Direct participation quality and organisational commitment: The role of leader-member-exchange. Employee Relations, 32(4), 418-434. doi:10.1108/01425451011051622

Vanaki, Z., \& Vagharseyyedin, S. A. (2009). Organizational commitment, work environment conditions, and life satisfaction among Iranian nurses. Nursing and Health Science, 11(4), 404-409. doi:10.1111/j.1442-2018.2009.00473.x

Villamizar Reyes, M. M., \& Castañeda Zapata, D. I. (2014). Relation Between Organizational Climate and its Dimensions and Knowledge-sharing Behavior among Knowledge Workers. International Journal of Psychological Research, 7(2), 64-75. doi: 10.21500/20112084.659

Zohar, D., \& Luria, G. (2005). A multilevel model of safety climate: Cross-level relationships between organization and group-level climates. Journal of Applied Psychology, 90(4), 616-628. doi:10.1037/0021-9010.90.4.616 


\subsection{Pregledni znanstveni članek}

\section{Primerjava organizacijskega vzdušja pred reorganizacijo in po njej v regijskem nacionalnem Zavodu za zdravstveno varstvo}

Zaposleni so biološka, kulturna in socialna bitja in so vsak dan v stiku z organizacijo. Organizacijska struktura in procesi ustvarjajo odnose, občutke in vedenja, ki tvorijo vzdušje ter so bistvo in gonilo vsake organizacije. Organizacija je živ, družaben in dinamičen sistem s skupinami ljudi, ki imajo različna duševna, ekonomska, socialna in kulturna ozadja in sodelujejo v medsebojnih stikih za doseganje skupnih ciljev, ki so dosegljivi le z vključitvijo vsakega posameznika v organizaciji.

Organizacijsko vzdušje je eden od ključnih elementov delovanja organizacije in je tesno povezano z vsemi procesi in deležniki v njej. Ima velik vpliv na oblikovanje vedenja zaposlenih ter pozitivno vpliva na učinkovitost. Zaposleni prepoznavajo pozitivno organizacijsko vzdušje in vedenje povezano z njim, kar se kaže v dobrih medosebnih odnosih, pozitivnem delovnem okolju in zadovoljstvu z delom; v nasprotnem primeru pa so razdraženi, nezadovoljni in nagnjeni h kontraproduktivnemu vedenju. V kolikor želi vodstvo popolnoma izkoristiti potencial zaposlenih, mora sooblikovati organizacijsko vzdušje in vplivati nanj, kar vpliva na celotno organizacijo. Produktivnost in zadovoljstvo zaposlenih sta odvisna od podpore v organizaciji.

Organizacijsko vzdušje vpliva na organizacijske ter psihološke procese, nanj pa vplivajo številni dejavniki znotraj organizacije. Vsaka sprememba $v$ organizaciji se odraža $v$ vedenju zaposlenih, $v$ njihovi motiviranosti in pripadnosti. Ekonomske, politične in kulturne spremembe v poslovnem okolju organizacijam pogosto otežujejo prilagajanje na novonastale okoliščine. Zato menedžerji vidijo meritve organizacijskega vzdušja kot enega od ključnih korakov pri celostni analizi organizacije.

Vprašalniki, namenjeni analiziranju organizacijskega vzdušja, se uporabljajo že več kot tri desetletja, saj omogočajo vpogled v njegovo stanje ter primerjavo med oddelki in drugimi organizacijami. V raziskavi smo uporabili prilagojeni SiOK-ov vprašalnik za merjenje organizacijskega vzdušja, ki je v uporabi v Sloveniji že dve desetletji.

Cilj raziskave je bila primerjava organizacijskega vzdušja v regionalni enoti Zavoda za zdravstveno varstvo pred reorganizacijo in po njej. Reorganizacija je proces organiziranja nečesa že obstoječega, vendar na drugačen način. Zavod, ki je bil ustanovljen $v$ 90ih in kontinuirano raste, je del javnega sektorja. V današnjem zahtevnem okolju je za vpeljavo sprememb potrebna oseba, ki ima 
znanja s področja delovanja; le tako bo organizacija še naprej delovala uspešno ter bo lahko svojim strankam nudila ustrezne izdelke oziroma storitve.

Reorganizacija zavoda je vključevala spremembo vodstva, saj je prišlo do združitve z drugim zavodom, prav tako je prišlo do zamenjave na vodilnih položajih skupaj s številnimi administrativnimi spremembami (poimenovanje zavoda, delovni obrazci, informacijski sistem itd.). Treba je omeniti, da je leta 2008 stopil v veljavo nov plačni sistem, s katerim so se plače zaposlenih v javnem sektorju znižale.

Naše raziskovalno vprašanje je bilo Ali je prišlo do izboljšanja organizacijskega vzdušja po reorganizaciji v regionalni enoti Zavoda za zdravstveno varstvo? Rezultati so pokazali, da pri nobeni dimenziji organizacijskega vzdušja ni prišlo do izboljšanja, zadeve so se le poslabšale. To nakazuje na pomanjkanje sodelovanja med vodstvom in zaposlenimi, ki je izjemnega pomena pri vpeljavi novosti ali sprememb. Raziskava je pokazala, da zaposleni ne zaupajo vodstvu in so se počutili premalo vključeni v proces reorganizacije. Zaradi tega niso imeli možnosti sodelovanja pri vpeljavi sprememb ter so bili posledično manj fleksibilni, saj niso vedeli, kaj naj pričakujejo.

Predhodne raziskave so pokazale, da organizacijsko vzdušje vpliva na motivacijo, odnos in zadovoljstvo zaposlenih, vendar mu menedžerji, čeprav se strinjajo o pomembnosti njegove vloge, še vedno ne posvečajo dovolj pozornosti; največja težava se kaže v pojmovanju in merjenju konstrukta, kljub temu da gre za enega izmed gradnikov organizacije. Če se rezultati merjenja organizacijskega vzdušja podcenjujejo, lahko to vodi k nezadovoljstvu, manjši motiviranosti in dolgoročno tudi poslabšanju odnosa do dela zaposlenih, v kolikor ne bi prišlo do spremembe stila vodenja.

Po opravljenem merjenju organizacijskega vzdušja je najprej potrebna identifikacija problematičnih področij. Naslednji korak je še pomembnejši, in sicer narediti je treba načrt, kaj se bo opravilo in do kdaj. Razvoj in napredek delovanja je treba stalno spremljati. $V$ ta proces morajo biti vključeni vsi zaposleni, najbolje $v$ mešanih timih (sestavljenih iz zaposlenih na različnih nivojih), saj se s tem dobi različne poglede na reševanje težav, izmenjavo idej ter znanja. Rezultati so pokazali, da je v zavodu stopnja notranje komunikacije in izmenjave informacij dobra, kar bi moral biti dober temelj za uspešen proces reorganizacije. Pozitivno organizacijsko vzdušje pozitivno vpliva na inovativnost in navdih ter pozitivno vpliva na doseganje organizacijskih ciljev.

Zaposleni v javnem sektorju potrebujejo optimalno organizacijsko vzdušje, zato je pomembno merjenje organizacijskega vzdušja pred reorganizacijo in po njej. Omejitev naše raziskave je bila v majhnosti vzorca, saj smo analizirali le en javni zavod v postopku reorganizacije; za primerjavo podatkov bi bilo primerno narediti analizo tudi z drugimi zavodi. Za nadaljnje raziskave predlagamo raziskovanje organizacijskega vzdušja $v$ povezavi z etičnim vzdušjem, organizacijsko pripadnostjo, zadovoljstvom z delom in s psihološkim opolnomočenjem. Predlagamo tudi primerjavo z zavodi v tujini. 